\title{
Evaluation of cassava leaf meal (Manihot esculenta Crantz) in feed with enzymes supplementation on broiler performances
}

\author{
Ririn Angriani ${ }^{1}$, Widya Hermana $^{2}$, and Muhammad Ridla ${ }^{2, *}$ \\ ${ }^{1}$ Graduate Study Program of Nutrition and Feed Science, IPB University, Bogor 16680, Indonesia \\ ${ }^{2}$ Department of Nutrition and Feed Technology, Faculty of Animal Science, IPB University, Bogor \\ 16680, Indonesia
}

\begin{abstract}
The research aimed to evaluate the effect of cassava leaf meal with enzymes supplementation in the feed on the performance of broiler. The research used factorial completly randomized design $2 \times 3$ on 240 Cobbstrain broilers. There were 6 treatments with 2 factors is used cassava leaf meal (CLM) and enzymes (non-starch polysaccharides and protease) with each dose $250 \mathrm{~g} /$ ton feed, i.e. $\mathrm{P}_{1}$ : basal ration, $\mathrm{P}_{2}$ : basal ration with enzymes, $\mathrm{P}_{3}$ : ration with $1.5 \%$ CLM, $\mathrm{P}_{4}$ : ration with $1.5 \%$ CLM and enzymes, $\mathrm{P}_{5}$ : ration with $3.0 \%$ CLM, $\mathrm{P}_{6}$ : ration with $3.0 \%$ CLM and enzymes. The variables analyzed were body weight, body weight gain, feed intake, feed conversion ratio, and mortality. The data obtained were analyzed by analysis of variance (ANOVA) and if the results indicated significantly different, then the post-hoc test conducted. The results showed that there was an interaction between CLM and enzymes on the feed conversion ratio $(P<$ 0.05 ). The addition enzymes can decrease feed conversion ratio (from 1.91 to 1.74$)$ siginificantly $(P<0.05)$. Addition CLM to a level of $3.0 \%$ did not interfere with performance. Enzymes can offset the detrimental effect caused by the use cassava leaf meal in the feed.
\end{abstract}

\section{Introduction}

Protein is one of the nutrients needed for broiler for growth and feed efficiency. The main source of protein in poultry feed is soybean meal, it has high protein and digestibility. Total import soybean was 2.48 million tons in 2020 [1]. One of the alternatives to overcome the dependence on imports was the utilization of local feedstuff protein source. Cassava is a local plant Indonesia that has high production. Cassava production in Indonesia was 19.3 million tons in 2018 [2]. The part of cassava is the tuber, skin of tuber, stem, and leaf. 10-40\% of cassava plants consist of leaves. Cassava leaf contain high crude protein, $\beta$-carotene, and minerals [3, 4]. Cassava leaves have active compounds of flavonoids, phenolics, and chlorophyll which is a natural antioxidant [3]. Crude protein content in cassava leaf meal reachs $23.78 \%$ [5]. The nutritional content of cassava leaf varies in each age [4]. The older the leaf, the protein and amino acid levels will decrease, while the crude fiber content will

\footnotetext{
*Corresponding author: hmridla@apps.ipb.ac.id
} 
increase. Cassava leaf meal levels $1.5 \%$ and $3.0 \%$ can increase weight gain with a lower feed conversion ratio [6].

Cassava leaves have a constrain. Crude fiber content in cassava leaf meal reaches $17.69 \%$ [5], while chickens have limitations in breakdown crude fiber due to the simple anatomy of the digestive tract of chickens. Cassava leaf have antinutrients such as cyanide acid (HCN). Several studies have been done to reduced the HCN levels $(58$ - $99 \%)$ through feed processing such as sun-drying [7]; oven-drying [8]; fermentation [9, 10], but the most effective method was the combination of chopping and sun-drying [11]. Cassava leaves have low digestibility due to the presence of antinutrients and high crude fiber. Low digestibility can be overcome by giving enzymes. The addition of non-starch polysaccharides (NSP) enzymes can optimize the breakdown of crude fiber and protease enzymes in feed can also optimize the use of protein. According to Ding et al. [12], the addition of protease enzymes can increase crude protein digestibility, trypsin activity, and intestinal morphology. NSP enzymes can overcome the problem of high fiber broiler feed [13]. This research aimed to evaluate the effect of addition of cassava leaf meal in feed with enzyme supplementation on the performance of broiler. Finally, it can be use as the reference of the utilization of cassava leaf meal in feed.

\section{Materials and methods}

\subsection{Animals and Feed}

This research used 1 day old-240 Cobb-strain broilers that kept in cage sized $100 \mathrm{~cm} \times 100$ $\mathrm{cm}$. Ration formulation adapted to nutrient requirements of broiler at pre-starter phase (age 1-7 days) based on SNI 8173.1:2015 [14], starter (age 7-21 days) based on SNI 8173.2:2015 [15], and finisher (age 21-35 days) based on SNI 8173.3:2015 [16]. Formulation and nutrients value of the experimental ration presented in Table 1 . The ration given to the pre-starter phase-chickens was the basal ration. Furthermore, the treatment ration was given starting from the starter phase until finisher. Feed was given twice a day, at 07.00 and 17.00 WIB (West Indonesian Time) and water was provided ad libitum.

The manufactured of ration began with the manufactured of cassava leaf meal (CLM). The cassava leaves that used were manggu cassava varietas with the red leaf-stem cassava, finger-shaped leaves, and aged 4-5 months old. Cassava leaves were taken from 15-20 leaves on the top of leaf plants. Cassava leaves were separated between the leaves and the stems. Furthermore, the fresh leaves were dried in the shade for 2-3 days, then put into the oven 24 hours with temperature of $60{ }^{\circ} \mathrm{C}$. The dried leaves were mashed by the grinder. The addition of enzymes was carried out with micro-feedstuffs mixtures such as amino acids and minerals during the mixing process. The enzyme used was NSP (Non-Startch Polysaccharide) with Superzyme-CS brand and protease with Concentrase-P brand. The enzyme each level used was $250 \mathrm{~g} /$ ton feed. Level of enzyme activity used can be seen in Table 2. The nutrient content that analyzed were dry matter and crude fiber based on method of SNI 01-2891-1992 [17]; crude protein, crude fat, and calcium (Ca) based on method of AOAC 2005 [18]; phosphor $(\mathrm{P})$ based on gravimetry method; and gross energy by bombcalorimeter. 
Table 1. Formulation and nutrients value of the experimental ration

\begin{tabular}{|c|c|c|c|c|c|c|c|}
\hline \multirow{2}{*}{ Feedstuffs } & \multirow{2}{*}{$\begin{array}{c}\text { Pre-starter (\%) } \\
\text { Basal }\end{array}$} & \multicolumn{3}{|c|}{ Starter $(\%)$} & \multicolumn{3}{|c|}{ Finisher (\%) } \\
\hline & & $\mathbf{K}_{\mathbf{0}}$ & $K_{1}$ & $\mathbf{K}_{2}$ & $\mathbf{K}_{\mathbf{0}}$ & $\mathbf{K}_{1}$ & $\mathbf{K}_{2}$ \\
\hline Maize & 54.00 & 56.00 & 56.00 & 56.00 & 59.00 & 59.00 & 59.00 \\
\hline Rice bran & 4.30 & 3.10 & 2.10 & 1.10 & 4.30 & 3.30 & 2.30 \\
\hline Soybean meal & 26.00 & 26.50 & 25.50 & 24.50 & 21.00 & 20.00 & 19.00 \\
\hline Cassava leaf meal & 0.00 & 0.00 & 1.50 & 3.00 & 0.00 & 1.50 & 3.00 \\
\hline Corn gluten meal & 8.00 & 7.00 & 7.00 & 7.00 & 8.00 & 8.00 & 8.00 \\
\hline Crude palm oil & 2.50 & 2.30 & 2.30 & 2.30 & 2.50 & 2.50 & 2.50 \\
\hline Fish meal & 2.00 & 2.00 & 2.50 & 3.00 & 2.00 & 2.50 & 3.00 \\
\hline Calcium carbonate & 1.00 & 1.00 & 1.00 & 1.00 & 1.10 & 1.10 & 1.10 \\
\hline $\begin{array}{l}\text { Dicalcium } \\
\text { phosphate }\end{array}$ & 1.10 & 1.30 & 1.30 & 1.30 & 1.30 & 1.30 & 1.30 \\
\hline Premix & 0.70 & 0.70 & 0.70 & 0.70 & 0.70 & 0.70 & 0.70 \\
\hline L-Lysine & 0.10 & 0.05 & 0.05 & 0.05 & 0.05 & 0.05 & 0.05 \\
\hline DL-Methionine & 0.10 & 0.05 & 0.05 & 0.05 & 0.05 & 0.05 & 0.05 \\
\hline Total & 100 & 100 & 100 & 100 & 100 & 100 & 100 \\
\hline \multicolumn{8}{|c|}{ Nutrients value } \\
\hline Dry matter (\%) & 85.91 & 85.77 & 85.88 & 85.88 & 85.70 & 85.82 & 85.93 \\
\hline Crude protein $(\%)$ & 22.33 & 22.87 & 22.86 & 22.86 & 21.22 & 21.21 & 21.20 \\
\hline Crude fat (\%) & 5.22 & 5.02 & 5.08 & 5.08 & 5.39 & 5.45 & 5.52 \\
\hline Crude fiber (\%) & 2.86 & 2.75 & 2.91 & 2.91 & 2.83 & 2.90 & 3.14 \\
\hline $\begin{array}{l}\text { Gross energy } \\
\text { (cal/g) }\end{array}$ & 3070.8 & 3074.2 & 3070.9 & 3070.9 & 3108.3 & 3104.9 & 3101.6 \\
\hline Calcium (\%) & 0.88 & 0.88 & 0.93 & 0.93 & 0.91 & 1.15 & 1.02 \\
\hline Phospor (\%) & 0.51 & 0.51 & 0.53 & 0.53 & 0.50 & 0.52 & 0.53 \\
\hline
\end{tabular}

K0: ration without CLM; K1: ration with $1.5 \%$ CLM; K2: ration with $3.0 \%$ cassava leaf meal

Table 2. Level of enzyme activity

\begin{tabular}{|l|c|c|}
\hline Enzyme & Enzyme activity in product (unit/g) & Enzyme activity in feed (unit/kg) \\
\hline Protease & 25000 & 6250 \\
\hline Non-Startch Polysaccharide (NSP) \\
\hline Xylanase & 2400 & 600 \\
\hline Glucanase & 300 & 75 \\
\hline Invertase & 1400 & 350 \\
\hline Protease & 2400 & 600 \\
\hline Cellulase & 1000 & 250 \\
\hline Amylase & 24000 & 6000 \\
\hline Mannanase & 120 & 30 \\
\hline Pectinase & 1700 & 425 \\
\hline
\end{tabular}

Source : Canadian Bio-System 


\section{Results and discussion}

The results research cassava leaf meal and enzymes on the body weight, body weight gain, feed intake, feed conversion ratio, and mortality as the performance variables for 35 days presented in Table 3.

Table 3. Effect of cassava leaf meal and enzymes levels on broiler performance for 35 days

\begin{tabular}{|l|c|c|c|c|}
\hline \multirow{2}{*}{ Parameter } & \multirow{2}{*}{ Feed } & \multicolumn{2}{|c|}{ Enzymes } & Average \\
\cline { 3 - 5 } & & Without & With & \\
\hline Body Weight $(\mathrm{g})$ & K0 & $792.44 \pm 0.77$ & $817.33 \pm 15.01$ & $804.89 \pm 16.62$ \\
\hline & K1 & $804.00 \pm 16.47$ & $816.45 \pm 11.76$ & $810.23 \pm 14.83$ \\
\hline & K2 & $800.80 \pm 15.36$ & $809.32 \pm 13.95$ & $805.06 \pm 14.33$ \\
\hline Average & & $799.08 \pm 13.27^{\mathrm{b}}$ & $814.37 \pm 12.63^{\mathrm{a}}$ & \\
\hline Body Weight Gain (g) & K0 & $748.71 \pm 0.12$ & $773.67 \pm 15.32$ & $761.19 \pm 16.76$ \\
\hline & K1 & $760.48 \pm 16.67$ & $773.00 \pm 11.75$ & $766.74 \pm 14.94$ \\
\hline & K2 & $757.58 \pm 15.45$ & $765.64 \pm 14.36$ & $761.61 \pm 14.46$ \\
\hline Average & & $754.59 \pm 13.41^{\mathrm{b}}$ & $770.77 \pm 12.85^{\mathrm{a}}$ & \\
\hline Feed Intake (g) & K0 & $1389.55 \pm 4.74$ & $1374.04 \pm 37.23$ & $1381.80 \pm 23.04$ \\
\hline & K1 & $1423.12 \pm 46.56$ & $1383.90 \pm 38.29$ & $1403.51 \pm 39.32$ \\
\hline & K2 & $1432.67 \pm 33.40$ & $1398.49 \pm 34.31$ & $1415.58 \pm 30.18$ \\
\hline Average & & $1415.11 \pm 32.18^{\mathrm{a}}$ & $1385.47 \pm 28.95^{\mathrm{b}}$ & \\
\hline Feed Conversion Ratio & K0 & $1.86 \pm 0.01^{\mathrm{b}}$ & $1.74 \pm 0.01^{\mathrm{e}}$ & $1.80 \pm 0.07$ \\
\hline & K1 & $1.87 \pm 0.02^{\mathrm{b}}$ & $1.79 \pm 0.02^{\mathrm{d}}$ & $1.83 \pm 0.05$ \\
\hline & K2 & $1.91 \pm 0.02^{\mathrm{a}}$ & $1.83 \pm 0.00^{\mathrm{c}}$ & $1.87 \pm 0.05$ \\
\hline Average & & $1,88 \pm 0,03$ & $1,78 \pm 0,04$ & \\
\hline Mortality (\%) & K0 & $0.14 \pm 0.24$ & $0.10 \pm 0.21$ & $0.12 \pm 0.20$ \\
\hline & K1 & $0.10 \pm 0.21$ & $0.00 \pm 0.00$ & $0.05 \pm 0.16$ \\
\hline & K2 & $0.10 \pm 0.21$ & $0.10 \pm 0.21$ & $0.10 \pm 0.19$ \\
\hline Average & & $0.12 \pm 0.19$ & $0.07 \pm 0.17$ & \\
\hline
\end{tabular}

Numbers followed with different superscript in same column-subgroup showed the significantly different $(P<0.05)$.

K0: ration without CLM; K1: ration with 1.5\% CLM; K2: ration with $3.0 \%$ CLM

There was no interaction between cassava leaf meal and enzymes on body weight and body weight gain, but addition of enzymes increase body weight and body weight gain significantly $(P<0.05)$. Feed with enzymes had higher final body weight and body weight gain, $814.37 \mathrm{~g}$ and $770.77 \mathrm{~g}$, respectively. In line with this finding, previous reports also showed that the addition of protease and NSP enzymes can increased body weight gain [13, $20,21]$. Supplementation of protease enzyme in low protein diets resulted in increased body weight due to the ability protease enzyme to increase absorption of nutrients [22]. This could be because the protease enzyme was able to increase protein digestibility so that protein from cassava leaf meal was utilized optimally. The used of NSP enzyme can also increase the digestibility of feed ingredients that have high fiber resulted in body weight gain [23, 24].

The final body weight of this study is below the Cobb standard, the body weight of 35 days old Cobb chickens can reachs $2 \mathrm{~kg}$. Addition cassava leaf meal up to level $3.0 \%$ did not interfere with performance. Ration without casssava leaf meal also have body weight below 
the Cobb standard. Environmental factors can cause body weight to not reach the standard. The temperature of the cage during the study ranged from $22.8-36.2^{\circ} \mathrm{C}$ with a humidity of $48-89 \%$. The ideal temperature for broiler rearing is $10-22{ }^{\circ} \mathrm{C}$ for achieving optimum body weight and $15-27{ }^{\circ} \mathrm{C}$ for ration efficiency [25]. According to Fatmaningsih et al. [26], chickens that feel uncomfortable with their environment can affect the physiological changes of chickens. The high environmental temperature can result in the accumulation of heat in the body, which will cause the livestock to experience heat stress. Stress reduction efforts have been carried out in this study, namely opening the curtains and turning on the fan at a high temperature and at night using the lamp as a heater. In addition, the provision of vitamins in drinking water is also carried out.

Addition of enzymes decrease feed intake significantly $(P<0.05)$. Feed with enzymes had a lower average of feed intake, but there was no interaction between cassava leaf meal and enzymes on feed intake. The research in line with Flores [27] and Kalmendal and Tauson [28] who report that protease and NSP enzymes can reduced feed intake. This was due to the adequacy of chicken in meeting the protein needs of the body. According to Risnajati [29], chickens have the ability to regulate feed consumption. The requirement of energy and protein affect the amount of feed consumption [6]. Protease enzyme can hydrolyze complex proteins into simpler compounds so as to optimize absorption [30].

The results showed that there was an interaction between cassava leaf meal and enzymes significant effect on the feed conversion ratio $(P<0.05)$. The results showed that cassava leaf meal increase FCR significantly $(P<0.05)$. The higher level of cassava leaf meal, the increased in feed conversion ratio. The research in line with Salu and Paembonan [6] shown that cassava leaf meal with levels $1.5 \%$ and $3.0 \%$ could increase weight gain with a lower feed conversion ratio, and more effective than $4.5 \%$ and $6.0 \%$ levels. This was due to the presence of cyanide acid in cassava leaf meal, so the more cassava leaf meal will make the cyanide acid (HCN) level higher. Based on the test results of cyanide acid content in cassava leaf meal, it was found that the addition of $1.5 \%$ CLM resulted in $1.19 \mathrm{mg} / \mathrm{kg}$ levels of HCN, while $3.0 \%$ CLM produced $2.38 \mathrm{mg} / \mathrm{kg}$ levels of $\mathrm{HCN}$.

The addition of cassava leaf meal with enzymes has a low feed conversion ratio. The addition enzymes can decrease feed conversion ratio (from 1.91 to 1.74 ) significantly $(P<$ 0.05 ). Feed conversion ratio is a parameter in seeing feed efficiency. It can be seen that the decrease in feed intake was in line with the decrease in feed conversion ratio and increased in body weight. Chickens without enzymes on their feed had high average conversion ratio than with enzymes. Previously, it was also showed that the use of protease and NSP enzymes can reduce feed conversion ratio [13, 21, 27, 28]. This was because protease enzymes were able to increase protein and amino acid digestibility so feed can be utilized properly [22]. Protease enzyme can also reduce the negative effects of anti-nutrients [12]. The used of NSP enzymes was able to reduce the detrimental effects of cassava leaf meal which has high fiber. Hydrolysis by NSP enzymes can release nutrients to cell walls and breakdown starch into simple sugars thereby increased nutrient absorption and feed digestibility efficiency [21]. The combination of NSP and protease can also optimize feeds containing high fiber, so increase the digestibility $[31,32]$.

There was no interaction between cassava leaf meal and enzymes on mortality. Based on the data the percentage of mortality was low about $0.00-0.14 \%$. Addition of cassava leaf meal and enzymes did not affect mortality. Most of the deaths in this study occurred during brooding. The brooding period is a critical period in the maintenance of DOC (Day Old Chick) from the age of 1-14 days. The ration given to the pre-starter phase-chickens was the basal ration, no addition cassava leaf meal and enzyme. Cause of the death occurs because management and disease [33]. Factors that affect health and performance in chickens are daily growth, type of light adaptation, and type of drinking place [34]. Yerpes et al. [35] 
divided the causes of death of broiler into two factors, they were internal factors (breeder age, sex, and type of DOC) and external factors (type of cage, season, and drinking water).

\section{Conclusion}

The ration with cassava leaf meal and enzymes supplementation has the best performance with the lowest value feed conversion ratio and does not adversely affect the broiler performance.

\section{References}

1. BPS - Statistics Indonesia, Imports of Soybean by Major Countries of Origin, 20102020 (2021) https://www.bps.go.id/statictable/2019/02/14/2015/impor-kedelaimenurut-negara-asal-utama-2010-2019.html

2. Ministry of Agriculture of the Republic of Indonesia, Cassava Production by Province, 2014-2018 (2018) https://www.pertanian.go.id/home/?show=page\&act=view\&id=61

3. S. Hasim, Falah, L. K. Dewi, Curr. Biochem. 3, 116-127 (2016)

4. C. Wobeto, A. D. Correa, C. M. P. Abreu, C. D. Santos, J. R. Abreu, Ciênc. Tecnol. Aliment. 26, 865-869 (2006)

5. N. K. Morgan, M. Choct, Anim. Nutr. 2, 253-261 (2016)

6. B. Salu, B. H. Paembonan, AgroSaint UKI Toraja, 1, 36-42 (2010)

7. N. Madalla, N.W. Agbo, K. Jauncey, Tanzan. J. Agric. Sci. 15, 1-12 (2016)

8. E. N. Junior, R. C. Chistea, R. S. Pena, Food Res. Int. 119, 517-523 (2019)

9. Hermanto, Fitriani, Jurnal Riset Teknologi Industri 12, 169-180 (2018)

10. B. R. S. Santos, E. F. R. Silva, L. A. C. Minho, G. C. Brandao, A. M. P. Santos, W. P. C. Santos, W. V. L. Silva, W. N. L. Santos, Microchem. J. 152, 104271 (2019)

11. A. O. Fasuyi, Pak. J. Nut. 4, 37-42 (2005)

12. X. M. Ding, D. D. Li, R. Li, J. P. Wang, Q. F. Zeng, S. P. Bai, Z. W. Su, K. Y. Zhang, Livest. Sci, 193, 26-31 (2016)

13. Z. Makhdum, H. Rehman, J. M. Larik, P. Bux, A. Hameed, J. Appl. Anim. Res. 41, 218222 (2013)

14. National Standardization Agency of Indonesia, SNI 8173.1-2015 Pakan Ayam Ras Pedaging (broiler) - Bagian 1: Sebelum Masa Awal (Pre Starter) (National Standardization Agency of Indonesia, Jakarta, Indonesia, 2015)

15. National Standardization Agency of Indonesia, SNI 8173.2-2015 Pakan Ayam Ras Pedaging (Broiler) - Bagian 2: Masa Awal (Starter) (National Standardization Agency of Indonesia, Jakarta, Indonesia, 2015)

16. National Standardization Agency of Indonesia, SNI 8173.3-2015 Pakan Ayam Ras Pedaging (Broiler) - Bagian 3: Masa Akhir (Finisher) (National Standardization Agency of Indonesia, Jakarta, Indonesia, 2015)

17. National Standardization Agency of Indonesia, SNI 01-2891-1992 Cara Uji Makanan dan Minuman (National Standardization Agency of Indonesia, Jakarta, Indonesia, 1992)

18. AOAC, Official Methods of Analysis of the Association of Analytical Chemists International, 18th edition (Association of Official Analytical Chemists, Maryland, USA, 2005) 
19. R. G. D. Steel, J. H. Torrie, D. Dickey, Principles and procedures of Statistics: A Biometrical Approach, 3rd Edition (McGraw Hill Inc., New York, USA, 1997)

20. A. K. Singh, J. F. D. Berrocoso, Y. Dersjant-Li, A. Awati, R. Jha, Anim. Feed Sci. Technol. 232, 16-20 (2017)

21. L. Yuan, M. Wang, X. Zhang, Z. Wang, PLOS ONE 12, e0173941 (2017)

22. M. Mohammadigheisar, I. H. Kim, J. Appl. Anim. Res. 46, 1377-1388 (2008)

23. K. Schedle, E. Humer, R. Leitgeb, G. Freudenberger, K. M. Ebner, C. J. Schwarz, Die Bodenkultur : J. Land Manag. Food Environ. 67, 185-198 (2016)

24. Z. Zduńczyka, J. Jankowskib, D. Mikuliskib, P. Zduńczyka, J. Juśkiewicza, B. A. Slominskic, Anim. Feed Sci. Technol. 263, 114448 (2020)

25. K. Nova, J. Anim. Sci. 10, 117-121 (2008)

26. R. Fatmaningsih, Riyanti, K. Nova, Jurnal Ilmiah Peternakan Terpadu 4, 222-229 (2016)

27. C. Flores, M. Williams, J. Pieniazek, Y. Dersjant-Li, A. Awati, J. T. Lee, J. Appl. Poult. Res. 25, 328-337 (2016)

28. R. Kalmendal, R. Tauson, Poult. Sci. 91, 1387-1393 (2012)

29. D. Risnajati, Jurnal Ilmiah Ilmu-Ilmu Peternakan 14, 62-67 (2011)

30. A. D. Anggraini, F. Poernama, C. Hanim, N. D. Dono, Buletin Peternakan 41, 243-249 (2017)

31. A. K. Singh, J. F. D Berrocoso, Y. Dersjant-Li, A. Awati, R. Jha. Poult. Sci. 98, 55715581 (2019)

32. M. Toghyani, S. B. Wu, R. A. P'erez-Maldonado, P. A. Iji, R. A. Swick, Poult. Sci. 96, 3960-3972 (2017)

33. A. Nurmi, M.A. Santi, N. Harahap, M.F. Harahap, Jurnal Ilmiah Peternakan Terpadu 6, 134-139 (2018)

34. T. Limbergen, S. Sarrazin, I. Chantziaras, J. Dewulf, R. Ducatelle, I. Kyriazakis, P. McMullin, J. Méndez, J. Niemi, S. Papasolomontos, P. Szeleszczuk, J. Van Erum, D. Maes, BMC Vet. Res. 16, 287 (2020)

35. M. Yerpes, P. Llonch, X. Manteca, Animals 10, 310 (2020) 